\title{
IFRS adoption, value relevance and conditional conservatism: evidence from China
}

\section{Cyrus Isaboke}

School of Accounting, Dongbei University of Finance and Economics, Dalian, China and Department of Finance, Karatina University, Karatina, Kenya, and

Yan Chen

School of Accounting, Dongbei University of Finance and Economics, Dalian, China
Received 9 September 2018 Revised 11 November 2018 Accepted 13 November 2018

\begin{abstract}
Purpose - This study sought to evaluate the relationship between value relevance of financial information and conditional conservatism of non-financial companies listed in China.

Design/methodology/approach - Using panel data comprising of 28,723 firm years, the authors determine the value relevance of financial information before and after mandatory International Financial Reporting Standards (IFRS) adoption while incorporating the relationship with conditional conservatism. The authors further examined how this relationship varies between state and non-state owned companies.

Findings - Conditional conservatism is positively (negatively) related to value relevance prior (post) to mandatory IFRS adoption while it makes no difference as to whether a company is state or non-state owned, as IFRS has a positive and significant effect on value relevance. Conservatism, on the other hand, has a negative and insignificant relationship with market value of both state and non-state owned firms during the pre- and post-IFRS period.

Originality/value - By exploring an emerging economy, the authors provide evidence on the variations in value relevance amongst state and non-state owned firms. In particular, the authors establish the positive effect of IFRS on the value relevance of non-state firms as compared to stateowned institutions.
\end{abstract}

Keywords China, IFRS, Value relevance, Conditional conservatism

Paper type Research paper

\section{Introduction}

Value relevance is a distinctive feature of financial reporting that is desirable at least according to International Accounting Standards Board (IASB). Tohmatsu (2010) indicates that where stock markets exist, in 123 jurisdictions, domestic listed companies are required to report according to International Financial Reporting Standards (IFRS) while 95 worldwide jurisdictions require unlisted companies to report according to the provisions of IFRS. Accounting standards in China have developed through time in accordance with the country's transformation to a mixed market-oriented economy. The Chinese accounting system was adopted from the Soviet Union that was primarily designed to provide accountability to the central government but they have gradually evolved to facilitate private ownership and foreign investment, (Lee et al., 2013) China applied a largely rules-based accounting regime that was industry specific thus it was difficult for diversified companies to produce consolidated accounts (Shields, 2010).

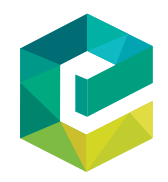

International Journal of Accounting \& Information Management No. 4,2019 
IJAIM 27,4

The Ministry of Finance of the People's Republic of China issued a new set of accounting standards for business enterprises (ASBEs), which substantially converged with IFRS. All listed companies in China were required to apply ASBEs for the preparation of their financial statements while application of IFRS as issued by IASB is not permitted (Deloitte, 2017). The standards cover nearly all topics in line with IFRS except for a few modifications made to cater for Chinese unique environment. Deloitte Touché Tohmatsu highlighted that the essential difference between IFRS adopted in China from that adopted in the EU is the import of fair value. Before mandatory adoption of IFRS in China, accounting information was mainly based on historical cost instead of fair value. The introduction of fair value measurement resulted in a mixed model that uses both fair and historical values. Further evidence indicates a significant drop in accounting conservatism after IFRS adoption. Numerous studies exist on the effects of IFRS adoption on accounting quality with mixed results, however, many researchers (Lang et al., 2003; Covrig et al., 2007; Chen et al., 2010) found the effects to be positive. Although IASB de-emphasizes the importance of conservatism, prior research (Watts, 2003) emphasizes on the importance of conditional conservatism regarding contractual processes and decision-making. Recent studies have emphasized on the effects of mandatory IFRS adoption while accentuating the western world. Manganaris et al. (2015) analyzed the effects of mandatory IFRS adoption and conditional conservatism on banks value. Using a sample of European banks, the authors found out that conditional conservatism is positively related to value relevance prior to IFRS adoption but negatively related after IFRS adoption. Notably absent is a study that explores this relationship among emerging markets while factoring in their unique characteristics and how the markets reacted during the pre- and post-financial crises period.

Basu (1997) and Khan and Watts (2009) suggested a significant reduction in accounting conservatism after IFRS adoption. Decreasing accounting conservatism can have opposite effects on accounting performance measures and their use in evaluation. It should increase the value relevance of accounting information because timely recognition of both good news and bad news makes accounting information more reliable (Manganaris et al., 2015). In this study, we seek to examine the level of value relevance before and after IFRS adoption and determine its relationship to conditional conservatism. We will further seek to determine how this relationship changed after mandatory IFRS adoption.

Using a sample of 28,723 firm years' observations for A-share listed firms in China from 1998 to 2016 period, we determine the effect of mandatory IFRS adoption on conditional conservatism. Using Basu (1997) and Khan and Watts (2009) model to measure conservatism and Aharony et al. (2010) approach to measure value relevance, we document evidence that answers the following empirical questions; What is the level of value relevance before and after IFRS adoption, the relationship with conservatism and how did it change after mandatory IFRS adoption? After controlling for industry and year effects our findings indicate that conservatism is negatively (positively) related to value relevance prior to (post) mandatory IFRS adoption.

Our study contributes to the IFRS literature by distinguishing itself from closely related studies by Luo et al. (2008), Ran and Huili (2008), Xue et al. (2008) and Zhang and Zhang (2008) in the following ways; we focus on an emerging market by comprehensively analyzing the relationship between mandatory IFRS adoption, value relevance and accounting conservatism in both the pre- and post-IFRS period. We further undertake additional subsample analysis based on whether a company is state or non-state owned and further analyze value relevance during the pre- and post-crisis period. Our research further investigates whether non-linearity between profit and loss entities has an effect on the value of a firm. These analyses suggest that IFRS adoption in China has been driven mostly by 
regulatory bodies combined with the reduction in accounting conservatism, which is somewhat similar to mature markets.

By exploring an emerging economy, we provide evidence on the variations in value relevance amongst state and non-state owned firms. In particular, we establish the positive effect of IFRS on the value relevance of non-state firms as compared to state-owned institutions.

\section{Literature review and hypotheses development}

Brown Jr et al. (2006) define value relevance as the summary provided by accounting earnings about information possessed in market prices. When making investment decisions, value relevance of earnings is useful for market participants (Lipe, 1986; Bowen et al., 1987; Barth et al., 1996). Conservatism is defined as the tendency to require faster recognition of "bad news" in relation to "good news" resulting to a higher degree of verification in financial statements (Basu, 1997). Timely recognition of "bad news" results to a type of conservatism known as conditional conservatism. Unconditional conservatism, on the other hand, refers to a "bias toward lower book values of equity and net assets in comparison to their net market value" (Manganaris et al., 2015). Mandatory IFRS adoption effects largely depend on whether they are of higher or lower quality than domestic generally accepted accounting principles (GAAP) (Ahmed et al., 2013). To illustrate this, Liu (2011) investigated whether reported net income as per US GAAP was comparable to net income as per IFRS as issued by the IASB. The study established an incomparable relationship at 5 per cent threshold for more than half of the companies that were sampled. Different treatment of business acquisition methods and asset revaluations were established to be the causes of incomparability while material comparability existed because of different accounting treatment of business combinations and tangible assets revaluation. Higher quality standards may entail reducing managerial discretion over accounting choices or disallow overstatement of accounting numbers. Voluntary adopters, on the other hand, choose to adopt IFRS, and thus, their incentives might be stronger in reporting higher quality accounting numbers.

Voluntary adopters exhibit decreased income smoothing and increased timeliness for loss recognition after adoption (Barth et al., 2008). Samples have been small and the results tend to be mixed. Bartov et al. (2005) in a study of the effect of adoption of IAS (precursor to IFRS) versus the German GAAP found an increase in the value relevance of earnings when firms switched to IAS from German GAAP while using a linear pricing model incorporating a pre- and post-design. Hung and Subramanyam (2007) examined the value relevance of restatement differences for 80 voluntary and early adopters of IAS using the "same firm year" design, which entails comparison between the relevance of local GAAP accounting measures as originally reported for the pre-IFRS adoption year with the relevance of the restated accounting measures for the same year, as presented in the comparative financial statements for the IFRS adoption year. Single and multiple country mandatory IFRS adoption studies also display mixed results. In a study of Australian firms, Goodwin et al. (2008) found out that the differences between IFRS and local GAAP have no incremental information for price in their samples and a similar result was previously obtained by Goodwin and Ahmed (2006). In a study of the common law and code law countries, Capkun et al. (2008) reported an increase in the incremental tests, which indicate that IFRS convey incremental value relevant information compared to local GAAP and so did (Wang, 2008), who found out that IFRS net income differences were positively associated with returns, indicating reliable incremental value relevance for IFRS earnings per share (EPS). Houqe (2018) conducted a key review of the literature on the determinants and consequences of 
IJAIM 27,4

IFRS adoption with a focus on the key issues that have an effect on adoption. The study established that adoption of IFRS has been successful in curbing information asymmetry, increasing information quality and positive influence on capital markets. It was further observed that positive effects of IFRS are allied to firms in strong enforcement regimes, which are incentivized to comply, and thus, recommended collaboration between standard setters and regulatory bodies worldwide. The role of corporate governance in IFRS convergence cannot be ignored. Chen and Rezaee (2012) in a study of IFRS convergence among B-share companies in China established that new Chinese standards were more aligned to IFRS as compared to the old standards and companies with an effective board tend to engage the big four firms as their auditors as they are aligned more to IFRS. Companies with effective boards were also likely to engage big four firms thus mediating the relationship between effectiveness of the board and IFRS convergence.

Value relevance and conditional conservatism are desirable features that improve the quality of accounting information but there are mixed results regarding relevance. Aubert and Grudnitski (2011) in a study of the impact and importance of mandatory adoption of IFRS on European firms found out that significant positive differences between return on assets calculated using IFRS and local GAAP were detected for firms in Belgium, Finland, France, Italy, The Netherlands, Sweden, Switzerland and UK while Germany and Norway displayed a negative significant difference. Clarkson et al. (2011) in a study on the impact of IFRS adoption in Europe and Australia found out that IFRS enhances comparability after using linear and non-linear pricing models. IFRS was found to have had an impact code and common law countries financial statements. Book value and earnings for code law countries were subsequently increased by IFRS thus conforming to the assertion that code law GAAP was conservative in nature. Pricing errors were observed when IFRS were adopted for common law countries relative to code law countries. Using the market based attributes, there was no change between book value, earnings and price indicating that IFRS adoption benefits are limited. Dayanandan $e$ al. (2016) examined the impact of IFRS between different legislative perspective in Europe by splitting the European sample into countries of French, English, Socialist, Scandinavian and German origin. They observed that 75 per cent of these countries were characterized by increased investor protection and there was less engagement in income smoothing after adoption of IFRS. Countries with civil law traditions were characterized by reduction of earnings management but no change was observed in common law countries because of strong investor protection and higher disclosure levels. Liu et al. (2011) examined the relevance and impact of IFRS on a regulated market that's under rapid change (China) and established improvement in accounting quality characterized by decreased earnings management and increased value relevance of reported earnings. The study further established that accounting quality was higher for firms that were not audited by the big four, which were less incentivized before the standard change. As an emerging economy, China has a relatively underdeveloped capital market that is characterized by more concentrated ownership whose legal enforcement is weak (Hou et al., 2014). Given the competing arguments on whether there's higher value relevance under IFRS as compared to local standards, we state our first hypothesis as follows:

H1. Mandatory IFRS adoption is positively related to value relevance of listed nonfinancial firms in China.

Manganaris et al. (2015) in a study of listed banks from 15 European countries found out that conditional conservatism is related to value relevance and mandatory IFRS adoption. The study revealed that global financial crisis was responsible for the bad performance of banks in the post-IFRS period. Market value to total assets (MV/TA), book value to total 
assets (BV/TA), returns, earnings to price (EPS/P) and change in earnings to price $(\triangle \mathrm{EPS} / \mathrm{P})$ deteriorated during the post-IFRS period as compared to the pre-IFRS period. Higher volatility of earnings was also established and this resulted to increased price volatility because of an increased level of information.

Ahmed et al. (2013) in a study of the effects of mandatory IFRS adoption on income smoothing, reporting aggressiveness and earnings management established that there was an increase in income smoothing after mandatory IFRS adoption, significant increase in reporting for accruals for IFRS firms relative to benchmark firms and also a significant reduction in timeliness of loss recognition for IFRS adopting firms. Aggregating their results, they found out that accounting quality decreased after mandatory IFRS adoption and the observations made largely held in countries where IFRS were strongly enforced. Adoption of IFRS has also been associated with decreasing cost of capital around the world, more so in the EU countries. Daske et al. (2008) found out that mandatory adopters experienced a decreased cost of capital in countries that had strict enforcement regimes. Specifically, a modest 28 basis points decrease was experienced in the EU. Early mandatory adopters possessed the following characteristics; the debt to equity ratio was low with a higher number of foreign sales and listings, larger capitalization and more diffuse ownership.

Regarding conservatism, existing literature has mostly highlighted its importance in financial firms. In a study of the US banking sector, Nichols et al. (2009) found out that listed banks exhibit higher levels of conservatism as compared to private banks. Furthermore, effective governance practices are directly related to accounting conservatism. Studies from developed markets have generated mixed results, which could be attributed to different samples and institutional settings but such cannot be applied to China, which has a closed but more modern economic system. Previous studies relating to China have indicated that IFRS adoption has had varied effects to accounting quality. Zhang and Zhu (2010) found out that after mandatory IFRS adoption, conservatism was reduced while Xue et al. (2008), Luo et al. (2008) and Ran and Huili (2008) found an enhancement in the relevance of accounting information under IFRS. Such studies indicate that there's no consistent conclusion about the effect of IFRS adoption in China. Regarding the relationship between value relevance and conservatism, the connotation between market value and accounting information is strengthened when there's timely loss recognition (Ball and Shivakumar, 2005). However, in a study of the Greek market, Kousenidis et al. (2009) postulate that high and low conservatism is connected to reduced levels of value relevance while medium conservatism is associated with increased levels of conservatism. Given the above literature and with the findings having no major predictive value for the study, we formulate our second hypothesis as follows:

H2. Conditional conservatism is negatively (positively) related to value relevance post (prior to) IFRS adoption in China.

\section{Research design \\ Conservatism}

Firm year conservatism is measured using Basu (1997) cross-sectional model on asymmetric timeliness. The model measures the timeliness of recognizing bad news in relation to good news. This timely recognition of bad news in relation to good news is a sign of conservatism.

To incorporate both firm and year variation in conservatism, the study utilizes Khan and Watts (2009) model, which incorporates firm-specific characteristics into consideration. This 
IJAIM

27,4

is made possible by specifying firm-year specific coefficients as linear functions of three characteristics (market to book ratio, size and leverage) as indicated below:

$$
\begin{gathered}
E P S_{i t} / P_{i t-1}=\beta_{1}+\beta_{2} D R_{i}+\beta_{3} \text { Ret }_{i t}+\beta_{4} D R_{i} * \text { Ret }_{i}+e_{i} \\
G-\text { score }=\beta_{3}=\mu_{1}+\mu_{2} \text { SizeMV }_{i}+\mu_{3} \frac{M}{B_{i}}+\mu_{4} \text { Leverage }_{i} \\
C-\text { score }=\beta_{4}=\gamma_{1}+\gamma_{2} \text { SizeMV }_{i}+\gamma_{3} \frac{M}{B_{i}}+\gamma_{4} \text { Leverage }_{i}
\end{gathered}
$$

where:

$\mathrm{EPS}_{\mathrm{it}} / \mathrm{P}_{\mathrm{it}-1}=$ Earnings per share before extraordinary items scaled by the share price taken three months after the year-end;

Ret $_{\text {it }}=$ Logarithmic stock return of firm $i$ at year $t$ measured three months after fiscal year-end;

$\mathrm{DR}_{\mathrm{it}}=$ Dummy variable that equals 1 if market return of firm $i$ for year $t$ is negative and 0 otherwise;

C-score = Conservatism score as estimated with the model of Khan and Watts (2009);

SizeMV = Natural logarithm of the market value of equity; and

Leverage $=$ Ratio of total debt to market value of equity.

C-score captures the timeliness of bad news while G-score captures the timeliness of good news. Combining Basu (1997) and Khan and Watts (2009) produces the following model, which allows us to measure conservatism:

$$
\begin{aligned}
\frac{\text { PPS }_{i t}}{P_{i t-1}}= & \beta_{1}+\beta_{2} D R_{i}+\left(\gamma_{1}+\gamma_{2} \text { SizeMV }_{i}+\gamma_{3} \frac{M}{B_{i}}+\gamma_{4} \text { Leverage }_{i}\right) \text { Ret }_{i t} \\
& +\left(\gamma_{1}+\gamma_{2} \text { SizeMV }_{i}+\gamma_{3} \frac{M}{B_{i}}+\gamma_{4} \text { Leverage }_{i}\right) \text { DR }_{i} * \text { Ret }_{i} \\
& +\left(\delta_{1} \text { SizeM }_{i}+\delta_{2} \frac{M}{B_{i}}+\delta_{3} \text { Leverage }_{i}+\delta_{4} D R_{i} * \text { SizeMV }_{i}\right. \\
& \left.+\delta_{5} D R_{i} * \frac{M}{B_{i}}+\delta_{6} D R_{i} * \text { Leverage }_{i}\right)+e_{i}
\end{aligned}
$$

Annual cross-sectional regressions on the models above were conducted and the estimate of the firm year conservatism calculated as the sum of the products of the estimators and the firm values of the three (size, market to book value and leverage). The resulting values were used as independent variables while determining value relevance.

\section{Value relevance}

To determine value relevance, we follow the approach used by Aharony et al. (2010), who incorporates both the price and return model to minimize bias. Existing literature provides mixed results when using both price and return value relevance models. 
Price model.

$$
\begin{aligned}
\frac{M V_{i t}}{T A_{i t-1}}= & a_{0}+\frac{a_{1} B V_{i t}}{T A_{i t-1}}+\frac{\alpha_{2} N I_{i t}}{T A_{i t-1}}+\alpha_{3} D L_{i t}+\alpha_{4} D L_{i t} * \frac{B V_{i t}}{T A_{i t-1}}+\alpha_{5} D L_{i t} * \frac{N I_{i t}}{T A_{i t-1}} \\
& +\alpha_{6} I F R S_{i t}+\alpha_{7} I F R S_{i t} * \frac{B V_{i t}}{T A_{i t-1}}+\alpha_{8} I F R S_{i t} * \frac{N I_{i t}}{T A_{i t-1}}+\alpha_{9} I F R S^{*} D L_{i t} \\
& +\alpha_{10} I F R S * D L_{i t} * \frac{B V_{i t}}{T A_{i t-1}}+\alpha_{11} I F R S * D L_{i t} * \frac{N I_{i t}}{T A_{i t-1}}+C-\operatorname{score}_{i t} \\
& + \text { IFRS } * C-\operatorname{score}_{i t}+\beta \text { Control }_{i t}+\varepsilon_{i t}
\end{aligned}
$$

where:

$\mathrm{MV} / \mathrm{TA}=$ The market value of the firm three months after fiscal year-end scaled by total assets of year $t-1$;

IFRS = Dummy variable that takes the value of 1 for the period after mandatory IFRS adoption and 0 if otherwise;

$\mathrm{NI} / \mathrm{TA}=$ Net income before extraordinary items deflated by total assets for the year $t-1$;

$\mathrm{BV} / \mathrm{TA}=$ Book value of a firm's equity for year $t$ deflated by total assets for year $t-1$; and

DL $\quad=$ Dummy variable representing 1 for loss reporting firms in year $t$ and 0 if otherwise.

Control Variables:

LogTA = The logarithm of total assets;

Leverage $=$ Ratio of total liabilities to common equity; and

BTM = Represents the ratio of book value of equity to market value of equity.

\section{Returns model.}

$$
\begin{aligned}
& \operatorname{Ret}_{i t}=a_{0}+\frac{a_{1} E P S_{i t}}{P_{i t-1}}+\frac{\alpha_{2} \Delta E P S_{i t}}{P_{i t-1}}+\alpha_{3} D L_{i t}+\alpha_{4} D L_{i t} * \frac{E P S_{i t}}{P_{i t-1}}+\alpha_{5} D L_{i t} * \frac{\Delta E P S_{i t}}{P_{i t-1}} \\
& +\alpha_{6} \operatorname{IFRS}_{i t}+\alpha_{7} \operatorname{IFRS}_{i t} * \frac{E P S_{i t}}{P_{i t-1}}+\alpha_{8} I F R S_{i t} * \frac{\Delta E P S_{i t}}{P_{i t-1}}+\alpha_{9} I F R S^{*} D L_{i t} \\
& +\alpha_{10} I_{F R S} * D L_{i t} * \frac{E P S_{i t}}{P_{i t-1}}+\alpha_{11} I F R S * D L_{i t} * \frac{\Delta E P S_{i t}}{P_{i t-1}}+C-\text { score }_{i t} \\
& + \text { IFRS }^{*} C-\text { score }_{i t}+\beta \text { Control }_{i t}+\varepsilon_{i t}
\end{aligned}
$$

where:

$\Delta E P S_{i t} / P_{i t-1}=$ change in earnings per share before extraordinary items scaled by the share price taken three months after the year-end.

To control the problem of scaling the price model variables are deflated by lagged total assets while the returns model variables are deflated using the stock price taken three months after the end of the lagged fiscal year. To address the possibility of non-linearity between profit and loss entities, we introduce a dummy loss variable, as it demonstrates higher informativeness than its interactions. This also further strengthen the validity of the 
IJAIM 27,4

expected results. Standard errors are adjusted to account for correlation within firm clusters thus controlling for potential heteroskedasticity. The marginal effects of specific variables were calculated and reported as follows; when IFRS equals one, the sum of the coefficients for both periods can be equated to one.

\section{Control variables}

A series of control variables were incorporated to determine if they affect the dependent variables. Size was used as one of them, as previous research indicates that larger firms are more value relevant as they display higher level of disclosures (Brimble and Hodgson, 2007) while smaller firms could be more informative because of lack of media exposure compared to larger firms (Beekes et al., 2004). It is expected that highly leveraged firms will exhibit lower earnings informativeness while rapidly growing firms will report higher earnings coefficients (Collins and Kothari, 1989; Kumar and Krishnan, 2008). This, therefore, justifies the need for incorporating leverage and growth in the models as control variables.

\section{Data and descriptive statistics}

Data are obtained from the China stock market and accounting research database, which offers data on the Chinese's companies' stock market and listed companies. The sample consists of A-share companies listed on the Shanghai and Shenzhen stock exchanges excluding financial industry firms. After excluding companies and observations whose data are not available, we remain with 28,723 firm year observations, which comprises of companies listed during the years 1998 to 2016 with majority of the firms belonging to the machinery, equipment and instrument sectors. The research period spans from 1998 to 2016, which is split into periods before (1998-2006) and after mandatory IFRS adoption (20072016). In the year 2006, the Ministry of Finance of the People's Republic of China issued a set of Accounting standards that converged with IFRS and required all listed companies to apply these ASBEs from January 2007. Based on the directive by the Ministry of Finance, it is presumed that companies adopted the ASBEs as instructed thus potential bias has been avoided because there are no voluntary IFRS adopters.

\section{Descriptive statistics}

Descriptive statistics for both the pre- and post-IFRS period are reported in Table II. Panel A indicates that the mean values of the variables are significantly different from zero. The mean values reported indicate an improvement in the post-IFRS period as compared to the pre-IFRS period except for the book to market value, which decreased in the post-IFRS period. This is in line with Barth et al. (2008), whose research on early mandatory IFRS adopters found out that accounting figures have been enhanced compared to the preIFRS period. Standard deviations have increased in the post-IFRS period except for the conservatism score variable. This implies that there's a lack of/declining conservatism in the post-IFRS era, which is in line with IASB provisions that deem conservatism as an undesirable characteristic of financial statements.

Conservatism on the other hand, is not significantly different in both the pre- and postIFRS period. This implies lack of conservatism in both the pre- and post-IFRS era - a characteristic that is desirable as per IASB as the board seems to favor it. This is in contrast to relevant literature, which deems it as a desirable characteristic of accounting quality. 


\begin{tabular}{lcclrr}
\hline Year & Observations & $(\%)$ & Industry & Observations & $(\%)$ \\
\hline 1998 & 666 & 2.32 & Construction industry & 586 & 2.04 \\
1999 & 767 & 2.67 & Electronic & 1,387 & 4.82 \\
2000 & 864 & 3 & Farming, forestry and animal husbandry & 671 & 2.33 \\
2001 & 999 & 3.47 & Food and beverage & 1,210 & 4.21 \\
2002 & 1,079 & 3.75 & Information technology industry & 2,093 & 7.28 \\
2003 & 1,142 & 3.97 & Integrated & 1,311 & 4.56 \\
2004 & 1,211 & 4.21 & Machinery, equipment and instrument & 5,136 & 17.86 \\
2005 & 1,310 & 4.55 & Manufacturing industry & 3 & 0.01 \\
2006 & 1,276 & 4.44 & Medicine and biologic products & 1,794 & 6.24 \\
2007 & 1,362 & 4.74 & Metal and nonmetal & 2,532 & 8.8 \\
2008 & 1,432 & 4.98 & Mining and quarrying & 493 & 1.71 \\
2009 & 1,533 & 5.33 & Other manufacturing & 405 & 1.41 \\
2010 & 1,678 & 5.83 & Papermaking and printing & 605 & 2.1 \\
2011 & 2,009 & 6.99 & Petroleum, chemical, rubber and plastic & 3,104 & 10.92 \\
2012 & 2,205 & 7.8 & Production and supply of power and gas & 1,109 & 3.86 \\
2013 & 2,383 & 8.29 & Realty business & 1,103 & 3.84 \\
2014 & 2,314 & 8.05 & Social services & 897 & 3.12 \\
2015 & 2,260 & 7.86 & Textile, clothing and fur & 1,164 & 4.05 \\
2016 & 2,233 & 7.76 & Timber and furniture industry & 103 & 0.36 \\
Total & 28,723 & 100 & Transmitting and culture industry & 258 & 0.9 \\
& & & Transportation and storage & 1,049 & 3.65 \\
& & & Wholesale and retail trades & 1,710 & 5.95 \\
& & & Total & 28,723 & 100
\end{tabular}

IFRS adoption

Notes: The sample consists of 28,723 firm-year observations for A-share non-financial listed companies in China from 1998 to 2016 (China stock market and accounting research database). The sample selection and distribution both by year and industry with the corresponding percentages are as indicated above

Table I.

Sample selection process

\section{Empirical results \\ Price model}

Table III presents the results from the price model, which includes dummy variables for mandatory IFRS adoption, firms that report losses and a couple of firm characteristics in form of control variables. These variables enhance the explanatory power of the model apart from solving the heterogeneity problem. Results from the price model indicate that IFRS is positive and significantly $\left(0.000714^{* * *}\right)$ related to value relevance thus leading us to accept our first hypothesis as stated. Conservatism is also established to be positively related to the firm values in the pre-IFRS period but has a negative relationship in the post-IFRS period. However, this relationship is insignificant in both periods but can be said to be consistent with the IFRS provisions that financial reporting should be more value relevant but less conservative whose implication might have contributed to the global financial crisis due to less conservative accounting practices by firms.

There is a significant decrease in the informative nature of book value of a firm's equity after the adoption of IFRS as indicated by the empirical findings. This relationship becomes negative and significant upon the introduction of the IFRS dummy an indication of the declining nature of book value informativeness after IFRS adoption. Further interaction with the loss dummy indicates a negative and significant relationship. This can be attributed to the principle-based standards that make it potentially difficult to circumvent by eliminating certain accounting alternatives thus reducing managerial discretion. 


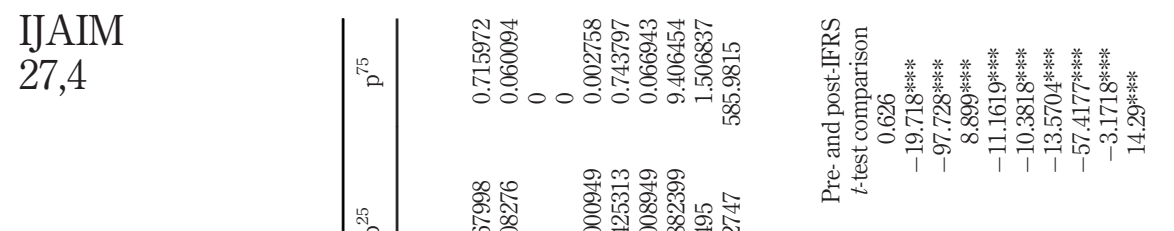

\section{8}

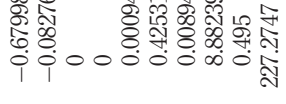

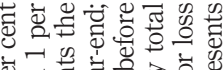

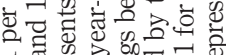

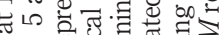

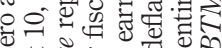

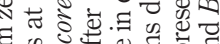

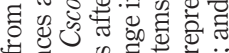

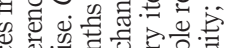

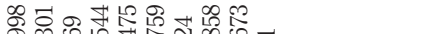

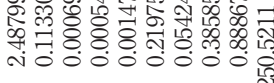

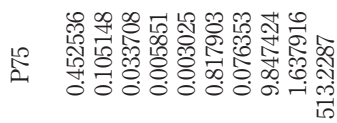

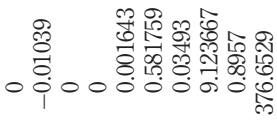

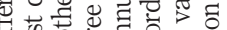

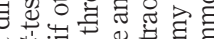

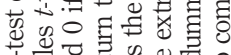

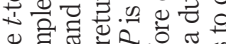
范获

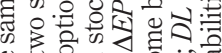

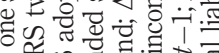
\%

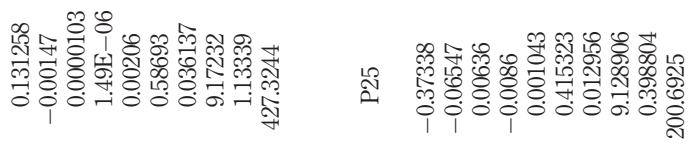

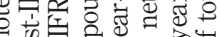

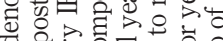
등ㅎㅀ

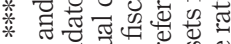

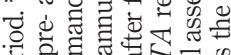

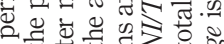
吕志重之。

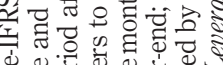

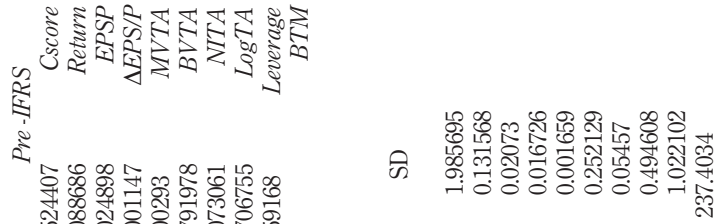
Q .

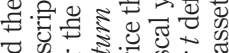

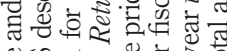

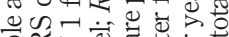

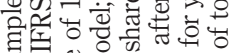

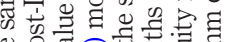
응

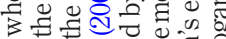

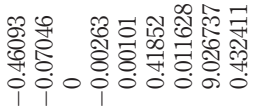

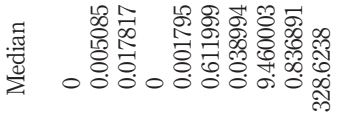
\& क \&

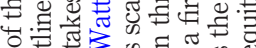

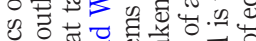
记

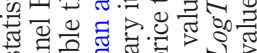
ڤ

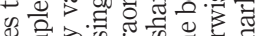

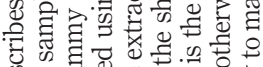

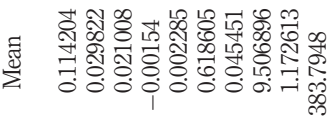

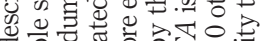
讨

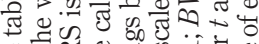

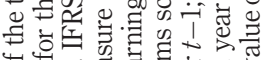

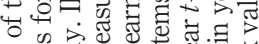

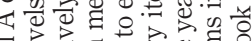

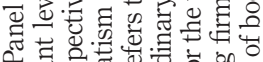
능 क

Table II.

Descriptive statistics

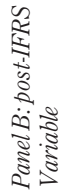

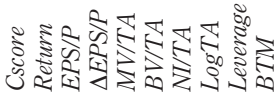

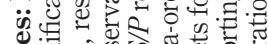

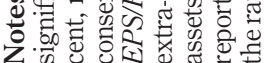




\begin{tabular}{|c|c|c|c|}
\hline Variable & Pre-IFRS coef. & Combined coef. & IFRS adoption \\
\hline Constant & $0.0109432 * * *(17.87)$ & $0.011352 * * * *(32.33)$ & \\
\hline$B V / T A$ & $0.0023105 * * *(29.41)$ & $0.002443 * * * *(38.17)$ & \\
\hline NI/TA & $0.0063798 * * *(18.34)$ & $0.004954 * * *(15.75)$ & \\
\hline$D L$ & $-0.000369 * * *(-4.29)$ & $-0.00075 * * *(-9.72)$ & \\
\hline$D L * B V / T A$ & $0.0013019 * * *(7.28)$ & $0.002288^{* * *}(13.84)$ & \\
\hline$D L^{*} N I / T A$ & $-0.007376 * * * *(-8.09)$ & $-0.00531 * * *(-6.62)$ & \\
\hline IFRS & & $0.000714^{* * * *}(12.75)$ & 539 \\
\hline IFRS*BV/TA & & $-0.00010 * * *(-1.63)$ & \\
\hline$I F R S^{*} D L$ & & $0.001045 * * *(8.85)$ & \\
\hline IFRS*NI/TA & & $0.002468^{* * *}(6.73)$ & \\
\hline$I F R S^{*} D L * B V / T A$ & & $-0.00378 * * *(-10.45)$ & \\
\hline$I F R S^{*} D L^{*} N I / T A$ & & $-0.002544(-0.95)$ & \\
\hline Cscore & $0.00000407(0.76)$ & $-0.00000109(-0.27)$ & \\
\hline IFRS*Cscore & & $0.00000949(1.28)$ & \\
\hline Control variables & & & \\
\hline$T A$ & $-0.0010945 * * *(-15.83)$ & $-0.001094 * * *(-38.9)$ & \\
\hline Leverage & $0.0001013 * * *(6.29)$ & $0.0001321 * * * *(13.43)$ & \\
\hline$B T M$ & $-0.00000134^{* * *}(-19.26)$ & $-0.0000019^{* * * *}(-47.46)$ & \\
\hline Industry fixed effects & Present & Present & \\
\hline Year fixed effects & Present & Present & \\
\hline Number of observations & 9,305 & 28,723 & \\
\hline$R^{2}$ & 0.6805 & 0.6543 & \\
\hline \multicolumn{3}{|c|}{$\begin{array}{l}\text { Notes: The dependent variable } M V / T A \text { is the market value of a firm three months after fiscal year-end } \\
\text { scaled by total assets of year } t-1 \text {. IFRS is a dummy variable that takes the value of } 1 \text { for the period after } \\
\text { mandatory IFRS adoption and } 0 \text { if otherwise. Cscore represents the conservatism measure calculated using } \\
\text { Khan and Watts (2009) model; NI/TA refers to net income before extraordinary items deflated by total } \\
\text { assets for the year } t-1 ; B V / T A \text { is the book value of a firm's equity for year } t \text { deflated by total assets for year } \\
t-1 ; D L \text { is a dummy variable representing } 1 \text { for loss reporting firms in year } t \text { and } 0 \text { otherwise; } T A \text { is the } \\
\text { logarithm of total assets; Leverage is the ratio of total liabilities to common equity; and } B T M \text { represents the } \\
\text { ratio of book value of equity to market value of equity. *** denotes significance levels at } 1 \text { per cent }\end{array}$} & $\begin{array}{r}\text { Table III. } \\
\text { Results for price } \\
\text { model }\end{array}$ \\
\hline
\end{tabular}

The interaction between net income and the loss dummy is negative and significant in both pre- and post-IFRS period, which is consistent with previous research (Hayn, 1995; Collins et al., 1997). It was further observed that the negative interaction term (between net income and loss dummy) increased in the post-IFRS period. This can be attributed to external factors like the global financial crisis that affected the performance of most firms after the year 2006. The informativeness nature of net income declines upon interacting it with loss and IFRS dummy - an indication that IFRS adoption does not result to a significant change in the losses incurred by a firm. An analysis of the control variables reveals that total assets, leverage and book to market ratio are significant in both the pre- and post-IFRS period.

\section{Return model}

Findings from the return model indicate that the informativeness nature of earnings in the post-IFRS period increased though insignificant. IFRS dummy is still positive and significant as postulated in the hypothesis but the change in EPS before extraordinary items became negative and significant in the post-IFRS period; an indication of the principled based nature of IFRS thus requiring the use of less alternatives. The loss dummy is significant in the pre-IFRS period but upon interaction with earnings and change in earnings, it becomes insignificant. This might be attributed to the declining 


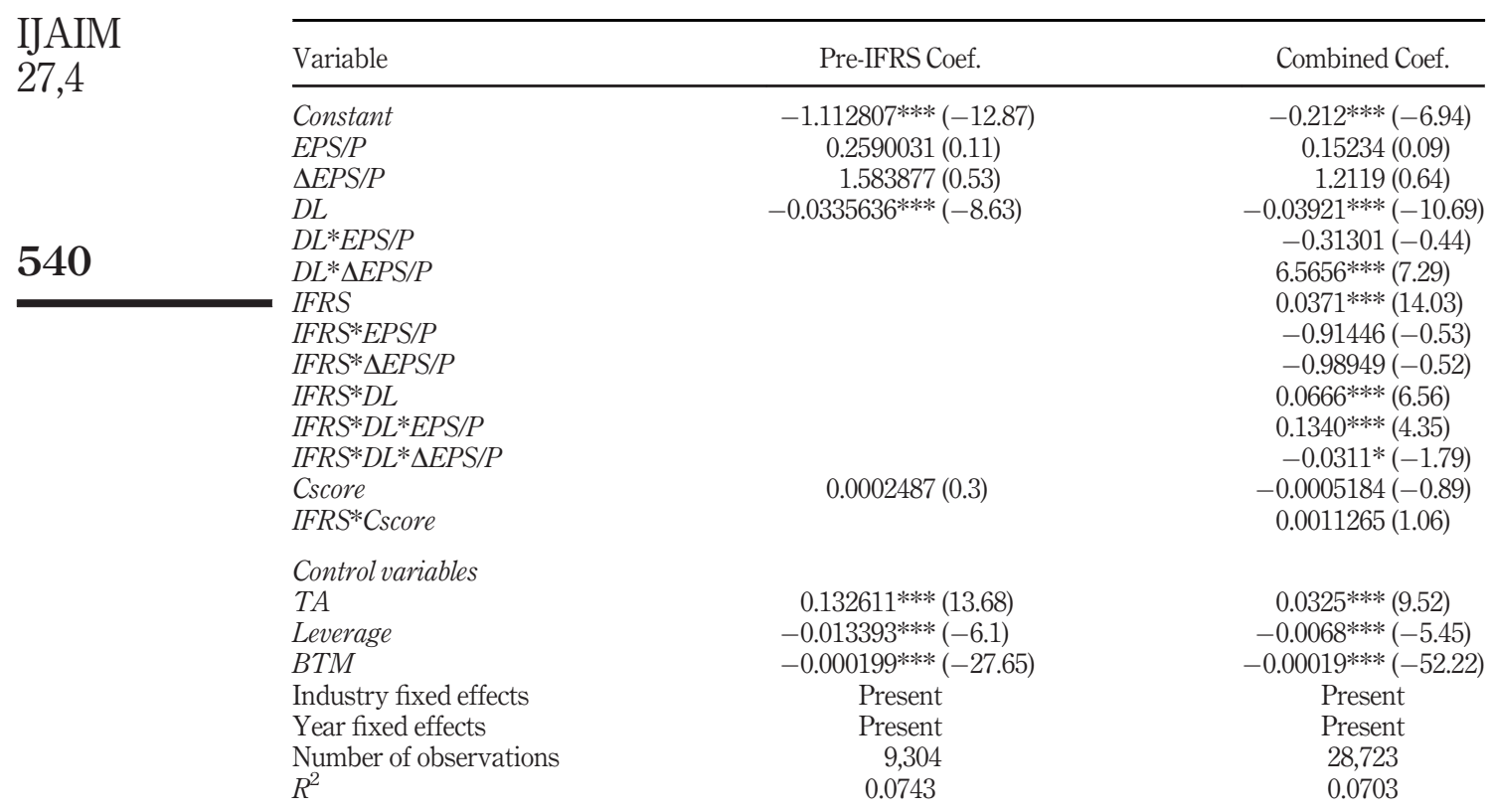

Notes: IFRS is a dummy variable that takes the value of 1 for the period after mandatory IFRS adoption and 0 if otherwise. Cscore represents the conservatism measure calculated using Khan and Watts (2009) model; EPSP refers to earnings before extraordinary items scaled by the share price three months after fiscal year-end; $\triangle E P S / P$ is the annual change in earnings before extra-ordinary items scaled by the share

Table IV.

Results for return model price taken three months after fiscal year-end; $D L$ is a dummy variable representing 1 for loss reporting firms in year $t$ and 0 otherwise; TA is the logarithm of total assets; Leverage is the ratio of total liabilities to common equity; and BTM represents the ratio of book value of equity to market value of equity. **** denotes significance levels at 1 per cent

nature of accounting quality as IFRS may have reduced the options for reporting the underlying finances of a business. Conservatism is positively related to returns in the pre-IFRS period but this relationship is reversed after 2006 and remains insignificant. $C$-score*IFRS shows a positive and insignificant increase, which is inconsistent with the desire of IASB that financial reporting should be more value relevant but less conservative. This implies that IFRS might have triggered the application of more conservative accounting practices thereby eliminating some accounting practices thus reducing managerial discretion.

Finally, the control variables signs and significant levels are consistent in both the preand post-IFRS period.

\section{Subsample analysis based on ownership}

We further conduct tests to determine whether IFRS adoption has effects on state and non-state owned firms. We introduce the variable StateDummy, which represents 1 if a firm is state-owned and 0 if otherwise. An analysis of the price model reveals that market value has a direct and significant relationship with StateDummy an indication that state-owned companies are expected to have higher returns. On the other hand, conservatism has a negative and insignificant relationship with market value of firms 


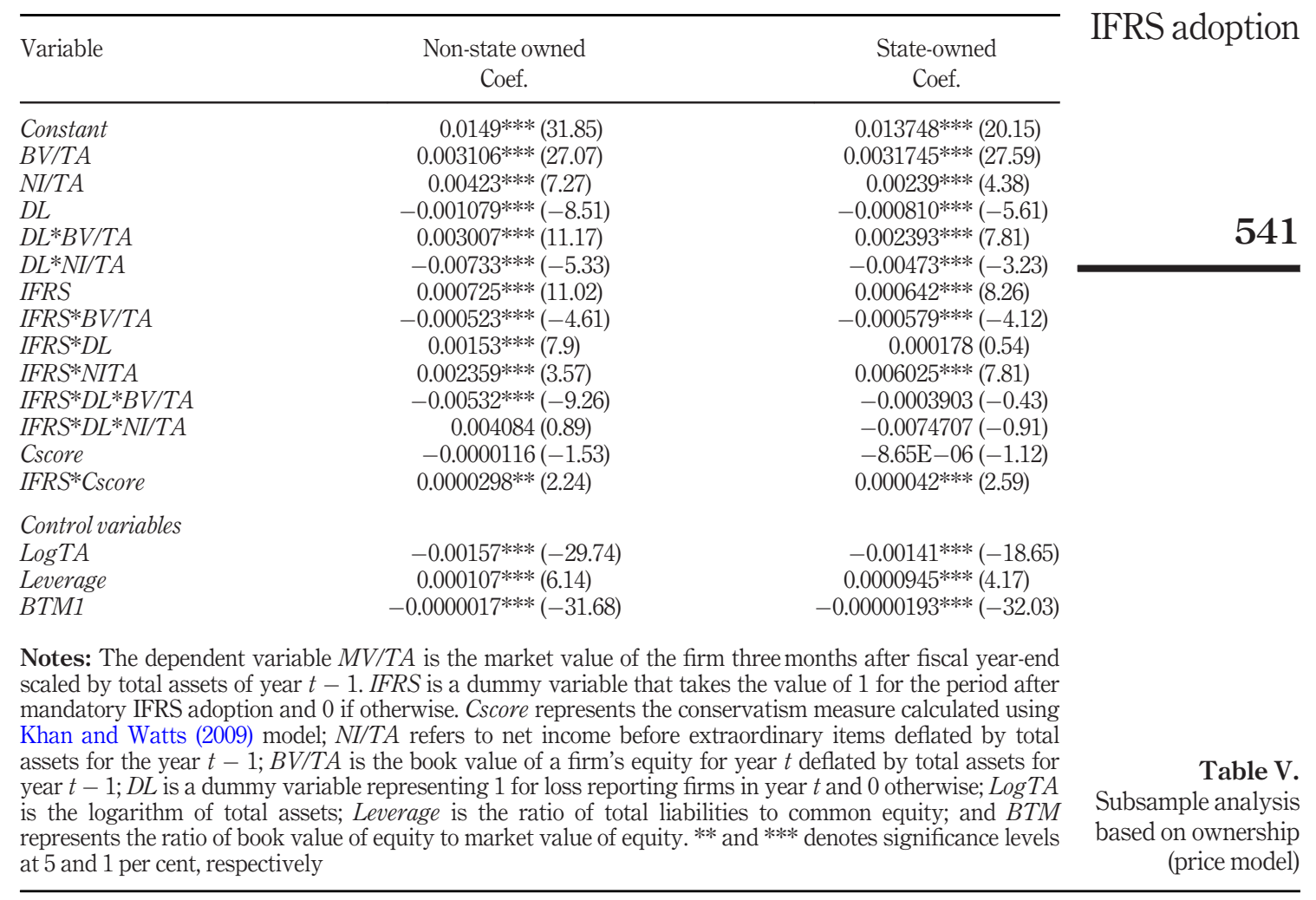

during the pre- and post-IFRS period. Interaction of the conservatism score and IFRS reveals a direct and significant relationship whose level increases in the state-owned companies. This is line with relevant previous literature, which deems conservatism to be an important feature of accounting quality though IASB deems it as an undesirable characteristic. It is also an indication of the extent to which non-state owned companies have embraced IFRS as compared to state-owned companies. Further analysis of the interaction of the loss dummy and the book value reveals that the relationship changes from direct to inverse (post-IFRS) an indication that IFRS may have led to improvements in reporting quality.

We also discern the pattern between earnings and value relevance under the returns model while considering whether a company is state or non-state owned. For non-state owned firms, the explanatory power of earnings is statistically significant and directly related to monthly returns. The same case applies to the annual change in earnings. In contrast, this relationship is positive but insignificant for state-owned firms - an indication that they are inclined toward meeting political objectives rather than shareholders interest. Conservatism, on the other hand, is insignificant and inversely related to both state and nonstate firms while interaction with IFRS exhibits mixed results though insignificant. This can be interpreted to mean that IFRS positively affects the returns of non-state firms while 


\section{IJAIM 27,4}

\begin{tabular}{|c|c|c|}
\hline Variable & $\begin{array}{l}\text { Pre-IFRS } \\
\text { Coef. }\end{array}$ & $\begin{array}{l}\text { Post-IFRS } \\
\text { Coef. }\end{array}$ \\
\hline Constant & $0.0168^{* * *}(19.14)$ & $0.017684^{* * * *}(37.09)$ \\
\hline BV/TA & $0.00344 * * *(34.75)$ & $0.002413 * * *(32.56)$ \\
\hline NI/TA & $0.00168^{* * * *}(3.6)$ & $0.00782 * * *(25.09)$ \\
\hline$D L$ & $-0.00125 * * *(-11.77)$ & $0.000414 * * *(4.29)$ \\
\hline$D L^{*} B V / T A$ & $0.0035 * * *(15.85)$ & $-0.000636 * * *(-2.96)$ \\
\hline$D L^{*} N I / T A$ & $-0.00591 * * *(-5.16)$ & $-0.00734 * * *(-7)$ \\
\hline StateDummy & $0.000115^{* * *}(2.88)$ & $0.000109 * * *(4.24)$ \\
\hline Cscore & $0.00000154(0.22)$ & $0.00000177(0.29)$ \\
\hline \multicolumn{3}{|l|}{ Control variables } \\
\hline $\log T A$ & $-0.00171^{* * * *}(-17.62)$ & $-0.00184^{* * *}(-35.12)$ \\
\hline Leverage & $0.0001232 * * *(5.85)$ & $0.00016 * * *(9.0)$ \\
\hline$B T M$ & $-0.00000286^{* * *}(-45.37)$ & $-0.00000059 * * *(-11.65)$ \\
\hline Industry fixed effects & Present & Present \\
\hline Year fixed effects & Present & Present \\
\hline$N$ & 7,772 & 11,498 \\
\hline$R^{2}$ & 0.5845 & 0.5046 \\
\hline
\end{tabular}

Table VI.

Ownership analysis for pre- and postIFRS periods
Notes: The dependent variable $M V / T A$ is the market value of the firm three months after fiscal year-end scaled by total assets of year $t-1$. IFRS is a dummy variable that takes the value of 1 for the period after mandatory IFRS adoption and 0 if otherwise. Cscore represents the conservatism measure calculated using Khan and Watts (2009) model; NI/TA refers to net income before extraordinary items deflated by total assets for the year $t-1 ; B V / T A$ is the book value of a firm's equity for year $t$ deflated by total assets for year $t-1 ; D L$ is a dummy variable representing 1 for loss reporting firms in year $t$ and 0 otherwise; $\log T A$ is the logarithm of total assets; Leverage is the ratio of total liabilities to common equity; and BTM represents the ratio of book value of equity to market value of equity. *** denotes significance levels at 1 per cent

negatively the state-owned ones. This might be attributed to the influence that political objectives have on performance of these firms rather than shareholders interest.

\section{Robustness tests}

This section entails a series of tests that we conducted to check the reliability of our results. Three tests were conducted to establish this. As postulated by Barth and Clinch (2009), we run the price model [Equation (2)] but deflate the variables with the market value of shares rather than total assets.

Untabulated regression results largely remain quantitatively similar to those previously reported with the conservatism measure (Cscore) being the only insignificant variable. As predicted in the hypothesis, IFRS adoption exhibits a positive and significant relationship with value relevance. The interaction between IFRS and the Cscore dummy becomes significant at the 5 per cent percent level contrary to previous findings - an indication that conservatism and relevance relationship can be fruitful in appropriate circumstances.

Our second test involved the market crises that have been experienced and the effect that they may have had over time. Hail (2013) postulates that occurrences associated with market crises affect value relevance over time. We, therefore, sought to perform further analysis, as the post-IFRS period overlaps with the period in which the global financial crisis was experienced. In line with the approach taken by Manganaris et al. (2015) we introduce a dummy variable (meltdown - MLTD) that represents one for the year 2008 and zero if otherwise. We include the dummy variable in the new model and its interaction with the rest 


\begin{tabular}{|c|c|c|}
\hline Variable & $\begin{array}{l}\text { Non-State Owned } \\
\text { Coef. }\end{array}$ & $\begin{array}{l}\text { State-Owned } \\
\text { Coef. }\end{array}$ \\
\hline $\begin{array}{l}\text { Constant } \\
E P S / P \\
\Delta E P S / P \\
D L \\
D L^{*} E P S / P \\
D L^{*} \Delta E P S / P \\
\text { IFRS } \\
\text { IFRS } E P S / P \\
\text { IFRS } \Delta E P S / P \\
\text { IFRS*DL } \\
\text { Cscore } \\
\text { IFRS*Cscore }\end{array}$ & $\begin{array}{c}0.0785(1.17) \\
2551.47 *(1.69) \\
-6712.21 * * *(-4.86) \\
-0.0445^{* * *}(-7.09) \\
-1.0213(-1.03) \\
9.606^{* * * *}(8.11) \\
0.0163 * * *(3.5) \\
-2551.26 *(-1.69) \\
6,712.17 * * *(4.86) \\
0.0950 * * *(6.51) \\
-0.000788(-0.75) \\
0.00173(0.94)\end{array}$ & $\begin{array}{c}-0.3101 * * *(-3.03) \\
0.4947(0.18) \\
0.7289(0.22) \\
-0.0311 * * *(-4.83) \\
1.1317(0.51) \\
19.094 * * *(9.11) \\
0.0679 * * *(10.46) \\
-1.0616(-0.39) \\
-1.0647(-0.32) \\
0.0943 * * *(2.95) \\
-0.00065(-0.57) \\
-0.00105(-0.44)\end{array}$ \\
\hline $\begin{array}{l}\text { Control variables } \\
\text { LogTA } \\
\text { Leverage } \\
\text { BTM } \\
N \\
R^{2}\end{array}$ & $\begin{array}{c}-0.00132(-0.18) \\
-0.002217(-1.06) \\
-0.000169 * * *(-23.56) \\
12,613 \\
0.0467\end{array}$ & $\begin{array}{c}0.0462 * * *(4.09) \\
-0.00416(-1.41) \\
-0.000253 * * *(-29.86) \\
6,654 \\
0.1715\end{array}$ \\
\hline
\end{tabular}

Notes: IFRS is a dummy variable that takes the value of 1 for the period after mandatory IFRS adoption and 0 if otherwise. Cscore represents the conservatism measure calculated using Khan and Watts (2009) model; EPSP refers to earnings before extraordinary items scaled by the share price three months after fiscal year-end; $\triangle E P S / P$ is the annual change in earnings before extra-ordinary items scaled by the share price taken three months after fiscal year-end; $D L$ is a dummy variable representing 1 for loss reporting firms in year $t$ and 0 otherwise; $\log T A$ is the logarithm of total assets; Leverage is the ratio of total liabilities to common equity; and $B T M$ represents the ratio of book value of equity to market value of equity. * and **** denotes significance levels at 10 and 1 per cent, respectively
IFRS adoption

Table VII.

Subsample analysis based on state ownership (returns model)

of the independent variables. Interaction of the dummy loss and net income revealed a significant relationship an indication that firms experienced remarkable decreases in their income during the financial meltdown period. A further interaction with the financial crisis dummy $(M L T D)$ invigorates this outcome. Regarding the return model, all interactions of the dummy loss $(D L)$ and financial crisis dummy $(M L T D)$ are significant in the post-crisis and IFRS period - an indication that firms experienced decreased earnings and losses during this period.

Our final sensitivity test involved determining whether conservatism and value relevance was affected by the crisis. Focusing on the post-IFRS period, we split it into two; pre-crises period (2005-2007) and post-crises period (2008-2014). Using the same models [Equation (3)], we replace the IFRS dummy with the crisis dummy. The interaction between conservatism and the new variable crisis is negative and statistically insignificant. This indicates an inverse relationship between value relevance in contrast to the previously observed one after IFRS adoption. Stringent supervision mechanisms were enforced by the various regulatory bodies to improve transparency and accountability. Results of the rest of the variables remain largely similar except for leverage, which becomes insignificant suggesting that in both the pre- and post-crisis period, its strength in describing firms' market value was diminished. 
IJAIM

27,4

\section{Conclusion}

IFRS adoption brought its challenges to the emerging markets and with its adoption in China, it has given rise to an increase in earnings management and decreased accounting conservatism. The study, therefore, sought to determine the effect of mandatory IFRS adoption on the value relevance of financial information of listed non-financial companies in China. Using a sample of 28,723 firm years we further explore the role of conditional conservatism in valuation. Decreasing accounting conservatism results to earnings being more natural and timely recognizing both good news and bad news. Furthermore, conservatism can be a desirable characteristic as described by various authors or undesirable based on the provisions of IASB, which emphasize on neutrality.

The price model depicts a decrease in the explanatory nature of book value and an increase in the informativeness nature of earnings. The return model, on the other hand, indicates that the informativeness nature of earnings in the post-IFRS period increased though the effect was insignificant. However, the change in EPS before extraordinary items became negative and significant in the post-IFRS period. Both models indicate that conservatism is positively related to the value of non-financial firms in the pre-IFRS period but this relationship reverses after adoption of IFRS - an indication that IFRS is associated with lower conservatism levels. Splitting the post-IFRS period into pre- and post-crisis does not have an effect on conservatism as it remains significant and negatively related to value relevance.

\section{References}

Aharony, J., Barniv, R. and Falk, H. (2010), "The impact of mandatory IFRS adoption on equity valuation of accounting numbers for security investors in the EU", European Accounting Review, Vol. 19 No. 3, pp. 535-578.

Ahmed, A.S., et al. (2013), "Does mandatory adoption of IFRS improve accounting quality? Preliminary evidence”, Contemporary Accounting Research, Vol. 30 No. 4, pp. 1344-1372.

Aubert, F. and Grudnitski, G. (2011), "The impact and importance of mandatory adoption of international financial reporting standards in Europe", Journal of International Financial Management and Accounting, Vol. 22 No. 1, pp. 1-26.

Ball, R. and Shivakumar, L. (2005), "Earnings quality in UK private firms: comparative loss recognition timeliness", Journal of Accounting and Economics, Vol. 39 No. 1, pp. 83-128.

Barth, M.E., et al. (1996), "Value-relevance of banks' fair value disclosures under SFAS no. 107", Accounting Review, Vol. 71, No. 4 (October), pp. 513-537.

Barth, M.E., et al. (2008), "International accounting standards and accounting quality", Journal of Accounting Research, Vol. 46 No. 3, pp. 467-498.

Barth, M.E. and Clinch, G. (2009), "Scale effects in capital markets-based accounting research", Journal of Business Finance and Accounting, Vol. 36 Nos 3/4, pp. 253-288.

Bartov, E., et al. (2005), "Comparative value relevance among German, US, and international accounting standards: a German stock market perspective", Journal of Accounting, Auditing and Finance, Vol. 20 No. 2, pp. 95-119.

Basu, S. (1997), “The conservatism principle and the asymmetric timeliness of earnings", Journal of Accounting and Economics, Vol. 24 No. 1, pp. 3-37.

Beekes, W., et al. (2004), "The link between earnings timeliness, earnings conservatism and board composition: evidence from the UK”, Corporate Governance, Vol. 12 No. 1, pp. 47-59.

Bowen, R.M., et al. (1987), "The incremental information content of accrual versus cash flows", Accounting Review, pp. 723-747. 
Brimble, M. and Hodgson, A. (2007), "On the intertemporal value relevance of conventional financial accounting in Australia", Accounting and Finance, Vol. 47 No. 4, pp. 599-622.

Brown, W.D., Jr, et al. (2006), "Conditional conservatism and the value relevance of accounting earnings: an international study", European Accounting Review, Vol. 15 No. 4, pp. 605-626.

Capkun, V. et al. (2008), "Earnings management and value relevance during the mandatory transition from local GAAPs to IFRS in Europe”, SSRN Electronic Journal, doi: 10.2139/ssrn.1125716.

Chen, H., et al. (2010), "The role of international financial reporting standards in accounting quality: evidence from the European Union", Journal of International Financial Management and Accounting, Vol. 21 No. 3, pp. 220-278.

Chen, Y. and Rezaee, Z. (2012), "The role of corporate governance in convergence with IFRS: evidence from China", International Journal of Accounting and Information Management, Vol. 20 No. 2, pp. 171-188.

Clarkson, P., et al. (2011), "The impact of IFRS adoption on the value relevance of book value and earnings", Journal of Contemporary Accounting and Economics, Vol. 7 No. 1, pp. 1-17.

Collins, D.W., et al. (1997), "Changes in the value-relevance of earnings and book values over the past forty years", Journal of Accounting and Economics, Vol. 24 No. 1, pp. 39-67.

Collins, D.W. and Kothari, S. (1989), "An analysis of intertemporal and cross-sectional determinants of earnings response coefficients", Journal of Accounting and Economics, Vol. 11 Nos 2/3, pp. 143-181.

Covrig, V.M., et al. (2007), "Home bias, foreign mutual fund holdings, and the voluntary adoption of international accounting standards", Journal of Accounting Research, Vol. 45 No. 1, pp. 41-70.

Daske, H., et al. (2008), "Mandatory IFRS reporting around the world: early evidence on the economic consequences", Journal of Accounting Research, Vol. 46 No. 5, pp. 1085-1142.

Dayanandan, A., et al. (2016), "IFRS and accounting quality: legal origin, regional, and disclosure impacts", International Journal of Accounting and Information Management, Vol. 24 No. 3, pp. 296-316.

Deloitte (2017), "Financial reporting framework in China", available at: www.iasplus.com/en/ jurisdictions/asia/china (accessed 30 November 2017).

Goodwin, J., et al. (2008), "The effects of international financial reporting standards on the accounts and accounting quality of Australian firms: a retrospective study", Journal of Contemporary Accounting and Economics, Vol. 4 No. 2, pp. 89-119.

Goodwin, J. and Ahmed, K. (2006), "The impact of international financial reporting standards: does size matter?”, Managerial Auditing Journal, Vol. 21 No. 5, pp. 460-475.

Hail, L. (2013), "Financial reporting and firm valuation: relevance lost or relevance regained?", Accounting and Business Research, Vol. 43 No. 4, pp. 329-358.

Hayn, C. (1995), "The information content of losses", Journal of Accounting and Economics, Vol. 20 No. 2, pp. 125-153.

Hou, Q., et al. (2014), "Mandatory IFRS adoption and executive compensation: evidence from China", China Journal of Accounting Research, Vol. 7 No. 1, pp. 9-29.

Houqe, N. (2018), "A review of the current debate on the determinants and consequences of mandatory IFRS adoption", International Journal of Accounting and Information Management, (justaccepted), 00-00.

Hung, M. and Subramanyam, K. (2007), "Financial statement effects of adopting international accounting standards: the case of Germany", Review of Accounting Studies, Vol. 12 No. 4, pp. 623-657.

Khan, M. and Watts, R.L. (2009), "Estimation and empirical properties of a firm-year measure of accounting conservatism", Journal of Accounting and Economics, Vol. 48 Nos 2/3, pp. 132-150.

Kousenidis, D.V., et al. (2009), "Value relevance of conservative and non-conservative accounting information”, The International Journal of Accounting, Vol. 44 No. 3, pp. 219-238. 
IJAIM 27,4

Kumar, K.R. and Krishnan, G.V. (2008), "The value-relevance of cash flows and accruals: the role of investment opportunities", The Accounting Review, Vol. 83 No. 4, pp. 997-1040.

Lang, M., et al. (2003), "How representative are firms that are cross-listed in the United States? An analysis of accounting quality", Journal of Accounting Research, Vol. 41 No. 2, pp. 363-386.

Lee, E., et al. (2013), "Does IFRS convergence affect financial reporting quality in China", ACCA Research Report, Vol. 131.

Lipe, R.C. (1986), "The information contained in the components of earnings", Journal of Accounting Research, Vol. 24, pp. 37-64.

Liu, C. (2011), "IFRS and US-GAAP comparability before release no. 33-8879: some evidence from USlisted Chinese companies", International Journal of Accounting and Information Management, Vol. 19 No. 1, pp. 24-33.

Liu, C., et al. (2011), "The impact of IFRS on accounting quality in a regulated market: an empirical study of China", Journal of Accounting, Auditing and Finance, Vol. 26 No. 4, pp. 659-676.

Luo, T., et al. (2008), "The effect of the new accounting standards on value relevance of accounting information”, China Accounting Review, Vol. 6 No. 2, pp. 129-140.

Manganaris, P., et al. (2015), "The effects of mandatory IFRS adoption and conditional conservatism on European bank values", Journal of International Accounting, Auditing and Taxation, Vol. 24, pp. $72-81$.

Nichols, D.C., et al. (2009), "Publicly traded versus privately held: implications for conditional conservatism in bank accounting", Review of Accounting Studies, Vol. 14 No. 1, pp. 88-122.

Ran, Z. and Huili, Z. (2008), "Economic consequences of the change on consolidated financial statement theory in the new accounting standards [J]", Accounting Research, Vol. 12 No. 006.

Shields, H. (2010), "Chinese accounting reform: towards a principles-based global regime”, The Institute of Chartered Accountants of Scotland 2010, Edinburgh.

Tohmatsu, D.T. (2010), "Use of IFRSs by jurisdiction”, Website IAS PLUS.

Wang, S. (2008), "Timing equity issuance in response to mandatory accounting standards change in Australia and the European Union”, Working Paper, Queens University, July 2008.

Watts, R.L. (2003), "Conservatism in accounting part I: explanations and implications", Accounting Horizons, Vol. 17 No. 3, pp. 207-221.

Xue, S., et al. (2008), "Does international convergence of accounting standards improve the value relevance of accounting information", Finance and Trade Economics, (in Chinese), Vol. 9, pp. $62-67$.

Zhang, R. and Zhang, H. (2008), "Economic consequences of the change on consolidated financial statement theory in the new accounting standards", Accounting Research, Vol. 12, pp. 39-46.

Zhang, X. and Zhu, S. (2010), "New accounting standards, fair value measurement and accounting conservatism", Working Paper, Tsinghua University (in Chinese).

\section{Corresponding author}

Cyrus Isaboke can be contacted at: isabokecyrus@hotmail.com

For instructions on how to order reprints of this article, please visit our website:

www.emeraldgrouppublishing.com/licensing/reprints.htm

Or contact us for further details: permissions@emeraldinsight.com 